\title{
The Need for Legal Regulation of Blockchain and Smart Contracts in the Shipping Industry
}

\author{
Marko Perkušića, Šime Jozipovićb, Damir Piplica ${ }^{a}$
}

The paper analyzes the potential impact of blockchain technology and smart contracts on the shipping industry. As the shipping industry represents a complex system of various actions that have to be controlled and registered, blockchain technology could serve as a tool to allow the streamlining of numerous processes, whilst at the same time taking the human factor out of multiple elements where trust between involved parties is an issue. The authors therefore first present how blockchain technology works and what smart contracts are, in order to give an insight into their applicability in the shipping sector. After a general overview of the technological and legal characteristics of blockchain technology and smart contracts, the authors present examples of relevant subjects, relations, and contracts in the shipping industry. Based on the charter party, a key contract in the shipping industry, the authors present the existing problems which could potentially be solved using blockchain technology.

\section{KEY WORDS \\ $\sim$ Blockchain \\ $\sim$ Smart contracts \\ $\sim$ Shipping industry \\ $\sim$ Shipping contracts \\ $\sim$ Charter party}

\begin{abstract}
a. University of Split, Department of Forensic Science, Split, Croatia
e-mail: maperku@gmail.com

b. , University of Split, Faculty of Economies, Bussiness and Tourism, Split, Croatia

e-mail: sime.jozipovic@efst.hr
\end{abstract}

doi: 10.7225/toms.v09.n02.019

This work is licensed under (cc) BY
Besides the benefits of blockchain technologies, the authors furthermore point out the existing deficiencies that still make blockchain technology hard to apply in legal relations within the shipping industry. Based on these insights, the authors highlight the current developments in this area and present the existing and expected regulatory reforms of blockchain solutions and smart contracts within the European Union.

\section{INTRODUCTION}

When someone mentions blockchain or smart contracts, most people will immediately think of virtual currencies like bitcoin, Litecoin, or ether. This is because both blockchain technology and smart contracts, as we know them today, originated from virtual currencies. In fact, the success of cryptocurrency like Bitcoin is one of the main arguments that advocates of blockchain point out when discussing the potential impact of this technology. However, blockchain and smart contracts are slowly starting to be used in other areas, such as insurance, construction, stock markets ${ }^{1}$, and of the course shipping industry. ${ }^{2}$ Because of its complexity and its essential

1. Perkušić, M. (2019): Legal Issues of Electronic Payment, Doctoral Dissertation, University of Rijeka, Faculty of Law, p. 399.

2. Some authors look at blockchain as a purpose technology that will be able to increase productivity, while others see blockchain as a technology that will change industrial organization. Blossey, G., Eisenhardt, J., Hahn, G. J. (2019): Blockchain Technology in Supply Chain Management: An Application Perspective, Proceedings of the $52^{\text {nd }}$ Hawaii International Conference on System Sciences|2019, URI: https:// hdl.handle.net/10125/60124 ISBN: 978-0-9981331-2-6 (CCBY-NC-ND4.0) p. 6886. ; Tapscott, D., Tapscott, A. (2017): "How blockchain will change organizations," MIT Sloan Management Review, vol. 58, no. 2, pp. 10-13. ; Babich, V., Hilary, G. (2018): "Distributed ledgers and operations: What operations management researchers should know about blockchain technology," SSRN Electronic Journal. 
value to the global market, ${ }^{3}$ the shipping industry is being placed in the very center of the adaptation of blockchain and smart contracts into their way of functioning. ${ }^{4}$ Numerous companies, countries, and academic institutions are working to implement blockchain technology. However, despite those efforts, the shipping industry has still proven to be resilient to the new technical and technological advancements. Various studies ${ }^{5}$ have shown that the reason for this is primarily linked to the nature of business between legal entities in the shipping industry ${ }^{6}$, while other authors have highlighted the need for regulation as a prerequisite for the growth of this field ${ }^{7}$. For this reason we are going to analyze the inner workings of blockchain and smart contracts, where they can be used (or are already being used) in the shipping industry (especially between legal entities) and identify the existing regulations that could apply to blockchain and smart contracts in the shipping industry. Based on the above conducted analysis, we then intend to determine whether there is a need for special regulation of blockchain and smart contracts in the shipping industry, which could help in their general application in order to reduce costs, save time, and generally increase the trust in the entire process ${ }^{8}$.

3. United Nations Conference on Trade and Development (UNCTAD) and the International Maritime Organization (IMO) have estimated that "in 2016 approximately $90 \%$ of world trade was transported by sea." Di Gregorio, R., Skjærset Nustad, S. (2017): Blockchain adoption in the shipping industry, A study of adoption likelihood and scenario-based opportunities and risks for IT service providers, Copenhagen Business School, Number of STUs: 272,322, p. 5.

4. It is stated that "blockchain implementation in the world of global trade could shake up traditional processes through automation and decentralization". Clott, C., Hartman, B., Beidler, B. (2020): Maritime Supply Chains, Chapter 10 - Sustainable blockchain technology in the maritime shipping industry, Elsevier Inc., p. 211.

5. Acciaro, M., Ferrari, C., Lam, J. S. L., Macario, R., Roumboutsos, A., Sys, C., et al. (2018): Are the innovation processes in seaport terminal operations successful? Maritime Policy \& Management, 45, p. 787-802. ; Vanelslander, T., Sys, C., Carlan, V. (2016): Innovation among seaport operators: A QCA approach for determining success conditions, International Journal of Transport Economics, 43, p. 291-314. ; Arduino, G., Aronietis, R., Crozet, Y., Frouws, K., Ferrari, C., et al. (2013): How to turn an innovative concept into a success? An application to seaport-related innovation, Research in Transportation Economics, Volume 42, Issue 1, June 2013., p. 97-107.

6. Bavassano, G., Ferrari, C., Tei, A. (2020): Blockchain: How shipping industry is dealing with the ultimate technological leap, Research in Transportation Business \&Management 34, 100428, available at: www.elsevier.com/locate/rtbm, accessed: 8. September 2020.

7. Pečarić M., Peronja l., Mostarac M. (2020)*: Application of "blockchain" and "smart contract" tehnology in international payments - the case of reimbursement banks, /Scientific Journal of Maritime Research/ 34 (2020) 166-177, Faculty of Maritime Studies Rijeka, p. $176 \mathrm{f}$.

8. As an example of current situation we can point out that "inter-firm information sharing systems are outdated and manual processes still prevail in the majority of its supply chain. This results in a lack of coordination among industry actors, poses security risks and an increased workload for authorities, reduces trust between parties doing business in the industry, and ultimately reduces the overall efficiency of business processes". Di Gregorio, R., Skjærset Nustad, S. (2017): op. cit. p. 6.; Jensen, T., Bjørn-Andersen, N., Vatrapu, R. (2014): Avocados crossing borders. Proceedings of the 5th ACM international conference on Collaboration across boundaries: culture, distance \& technology-CABS '14.

\section{BLOCKCHAIN OVERVIEW}

As has been already mentioned above, blockchain technology originates from virtual currencies, bitcoin cryptocurrency to be exact, ${ }^{9}$ and as such has been analyzed many times. ${ }^{10}$ That is why we are only going to point out the main features of blockchain, as well as its segmentation into public and permissioned blockchain which is important in establishing the way in which a blockchain could fulfill all the requirements of the shipping industry.

Before defining blockchain we have to emphasize that there is not a general definition of blockchain that is widely accepted. There is rather a wide range of definitions in which authors are looking at blockchain from different aspects. Having that fact and the subject of our paper in mind, we deem that blockchain can be defined as "a distributed database, which is shared among and agreed upon a peer-to-peer network. It consists of a linked sequence of blocks, holding timestamped transactions that are secured by cryptography and verified by the network community. Once an element is appended to the blockchain, it cannot be altered, turning a blockchain into an immutable record of past activity".11 From that definition we can conclude that the main characteristics of blockchain are:

- It is a distributed database (data is not saved in one place, rather it is dispersed through a network of interconnected computers),

- It is shared among and agreed upon by peer-to-peer network (peers make a peer-to-peer network and they are equal participants who enable a network to function for all participants without the need for central coordination, and they do so by allowing their computers to perform the tasks the network requires),

9. Satoshi Nakamoto (creator of bitcoin) defines a bitcoin as "a chain of digital signatures recorded by a distributed time-stamp server in a cryptographically secured ledger called the Block Chain". Pflaum, l., Hateley, E. (2014): A bit of a problem: National and extraterritorial regulation of virtual currency in the age of financial disintermediation, Georgetown Journal of International Law, vol. 45, p. 1174. ; Nakamoto, S. (2008): Bitcoin: A Peer-to-Peer Electronic Cash System, available at: https://bitcoin.org/bitcoin.pdf, accessed: 8. September 2020., p. 1.

10. See Kiviat, T. I. (2015): Beyond Bitcoin: Issues In Regulating Blockchain Transactions, 65 Duke Law Journal; Kütük-Markendorf, M. E. (2016): Rechtliche Einordnung von Internetwährungen im deutschen Rechtssystem am Beispiel von Bitcoin, PL Academic Research; Blocher, W. (2016): The next big thing: Blockchain - Bitcoin - Smart Contracts, 71. Deutsche Juristentag - Anwaltsblatt 8-9. ; Ryan, P. (2017): Smart Contract Relations in e-Commerce: Legal Implications of Exchanges Conducted on the Blockchain, Technology Innovation Management Review, Volume 7, Issue 10. ; Bouidani, M. M. (2019): Design and Implementation of Blockchain Shipping Application, A Thesis Submitted in Partial Fulfilment of the Requirements for Degree of Master of Applied Science in the Department of Electrical and Computer Engineering, University of Victoria.

11. Seebacher, S., Schüritz, R. (2017): Blockchain Technology as an Enabler of Service Systems: A Structured Literature Review. Lecture Notes in Business Information Processing Exploring Services Science, p. 14. 
- It consists of a linked sequence of blocks (records in blockchain are stored through blocks which contain data and are connected with one another through a cryptographic authentication called hashing which then forms a blockchain),

- It uses timestamps (data points that show when each block was connected in a chronological order and it is tamper-proof),

- It is secured by cryptography (a system that links blocks together and enables secure transmission and exchange of digital data in a decentralized manner),

- It is verified by the network community (no centralized authority exists but all verification is conducted by peers),

- It cannot be altered (to alter the existing data on a blockchain one would have to do it retroactively and need to alter all subsequent blocks. To be able to do this one would have to have the consensus of the network majority).

As we have already mentioned, blockchain is divided into public and permissioned blockchain. The main characteristic of a public blockchain (which most of cryptocurrencies are using) is that anyone can use the protocol and be a part of a peer-topeer network. This openness makes the network transparent and decentralized. A permissioned blockchain is very similar to a public one. The main difference is, however, that it is not open, which means that if someone wants to join the network he or she needs permission, therefore only an agreed set of readers and writers have the authorization to interact with the blockchain. $^{12}$ There is a further division of permissioned blockchain into consortium blockchain and private blockchain. ${ }^{13}$ The difference is that in a consortium blockchain there is a consortium of parties that has a common interest in some ledger, ${ }^{14}$ while private blockchain is used by a private company for internal use. ${ }^{15}$ In recent years permissioned blockchain is becoming more and more popular, especially between entities that have a certain degree of trust between each other and do not want their data (like contacts in digital form) to be saved on a public network, even though there are ways to keep certain information private on the public blockchain. ${ }^{16}$ Because of that

12. Harshvardhan (2018): Improving shipping contracts with the use of emerging technologies, Master of Engineering in Supply Chain Management at the Massachusetts Institute of Technology, p. 24.

13. Buterin, V. (2015): "Crypto Renaissance Salon - On Public and Private Blockchains", retrieved from https://blog.ethereum.org/2015/08/07/on-public-and-privateblockchains; Harshvardhan (2018): op. cit. p. 24.

14. Similar division of blockchain is also made where blockchain is divided on public blockchain, fully private blockchain, and federated or consortium blockchain for which it is highlighted that it is mostly used in banking sector. Jain, P. (2018): Improving the process of container shipping using blockchain, Master of Applied Science in Supply Chain Management at the Massachusetts Institute of Technology, p. 15-16.

15. Buterin, V. (2015): "Crypto Renaissance Salon - On Public and Private Blockchains", retrieved from https://blog.ethereum.org/2015/08/07/on-public-and-privateblockchains; Harshvardhan (2018): op. cit. p. 24.

16. For example by using zk-SNARK Technique (Zero-Knowledge Succinct NonInteractive Argument of Knowledge). Harshvardhan (2018): op. cit. p. 25. certain degree of trust between the entities that use permissioned blockchain, consensus mechanisms are much easier to use in permissioned blockchain and, due to this fact, it is cheaper and faster than public blockchain. However, if entities do not trust each other, only a public blockchain can completely protect them in a way they know that nobody could have modified the stored data. The above mentioned segmentation of blockchain, as well as its definition and main characteristics, will be important when we come to the part of this paper where we establish in which aspects of the shipping industry blockchain could be generally used and what form of blockchain would be most suitable for it.

\section{SMART CONTRACTS OVERVIEW}

The idea of a smart contract was created by Nick Szabo in 1994 when he defined a smart contract as a "computerized transaction protocol that executes the terms of a contract". ${ }^{17}$ However, the first smart contract system was created in 2014 on the Ethereum platform, using Ehter cryptocurrency and functions with public blockchain technology.

Even though it is called a smart contract, from a legal point of view, we believe that smart contracts are not primarily contracts or forms of a contract, but usually a way to implement or execute a contract. ${ }^{18}$ Therefore, smart contracts can be defined as a way of executing predefined criteria and conditions on which two or more parties agree to in order for them to execute themselves independently using computer code located on the blockchain network. ${ }^{19}$ The basic configuration of smart contracts consists of four phases:

1. The conclusion a contract whose terms and conditions are then being translated into a code;

2. The chain of events where the obligations defined in the contract begin to be fulfilled;

3. The If-this-then-that phase where the code activates the transfer of value, if terms and conditions are met;

4. The settlement where contractual obligations have been fulfilled and saved on the blockchain..$^{20}$

There are many positive aspects of smart contracts that are often highlighted in academic literature. For example, their ability

17. Szabo, N. (1994): Smart Contracts, retrived from: http://www.fon.hum.uva.nl/ rob/Courses/Information/nSpeech/CDROM/Literature/LOTwinterschool2006/ szabo.best.vwh.net/smart.contracts.html; Gans, J. S. (2019): The fine print in smart contracts, NBER Working Paper Series, Working Paper 25443, available at: http:// www.nber.org/papers/w25443, p. 2.

18. Perkušić, M, Jozipović, Š., Mamut, J. (2020): Mogućnosti korištenja i pravnog uređenja tzv. pametnih ugovora u Republici Hrvatskoj, Slakoper, Z., Tot, I. (ur.), Hrvatsko obvezno pravo u poredbeno-pravnom kontekstu: Petnaest godina Zakona o obveznom odnosima, Ekonomski fakultet Sveučilišta u Zagrebu, Zagreb, p. 8.

19. Perkušić, M, Jozipović, Š., Mamut, J. (2020): op. cit. p. 8

20. See similar Pilavci, E. E. (2019): The Regulation of Smart Contracts: Law, Governance and Practice, ISTANBUL BILGI ÜNIVERSITESI LISANSÜSTÜ PROGRAMLAR ENSTITÜSÜ BILISSIM VE TEKNOLOJI HUKUKU YÜKSEK LISANS PROGRAMI, p. 8.- 
to increase contractibility and facilitate exchange of anything of value (money, shares, service, etc.) without conflict and in an algorithmically automated way. ${ }^{21}$ Smart contracts are often being compared with conventional contracts, even though they are not perfectly comparable. As key benefits of smart contracts it is for example pointed out that they: (1) reduce risks as they are saved on an inalterable blockchain, (2) cut down administration and service costs as automation substitutes the need for a mediator or a central broker, and (3) improve the efficiency of business processes by cutting out intermediaries from the process ${ }^{22}$ Although there are many benefits of smart contracts, later in this paper we show how they are used (or are attempted to be used) in the shipping industry, and we analyze the problems that emerge in their application in practice.

\section{PROBLEMS OF THE SHIPPING INDUSTRY}

Although the business of moving cargo from point $A$ to point $B$ on the surface might seem as a rather simple endeavour, the modern shipping industry is a complex amalgamation of various activities, businesses entities, and often diverging interests of involved parties. As an example we can use the tanker shipping market and the contracts related to this area. In a typical movement of liquid bulk cargo ${ }^{23}$ from one port to another, multiple legal entities are involved, namely:

- The Consignor (supplier) - is engaged in exporting the commodity which he has produced or purchased from a producer;

- The Consignee (receiver) - is the importer of the commodity;

- Port terminals - act as facilitators of loading and unloading operations aboard a ship;

- $\quad$ Port authorities - navigate ships within their waters and are responsible for their safe navigation;

- $\quad$ Traders - find demand-supply gaps and trade with that commodity to make a profit;

- Charterers - handle logistics for movement of commodity for traders and are often part of the same organization as the traders;

21. Chong, L. W., He, Z. (2019): Blockchain Disruption and Smart Contracts, The Review of Finanial Studies I v 32 n 5, p. 1762.

22. Zheng, Z., Xie, S., Dai, H., Chen, W., Chen, X., Weng, J., Irman, M. (2019): An Overview on Smart Contracts: Challenges, Advances and Platforms, Journal Pre-proof, To appear in : Future Generation Computer Systems, PII: S0167-739X(19)31628-0, DOI: http://doi.org/10.1016/j.future.2019.12.2019., p. 2.

23. Bulk shipping is transport of bulk commodities that represent large parcels of semi-manufactured goods and raw materials (coal, grain, oil, etc.). Similar to bulk shipping, there are liner shipping and specialized shipping. Liner shipping represents transport of small parcels of semi-manufactured and manufactured goods (general cargo), while specialized shipping represents transport of large consignments of goods which are difficult to handle (cars, trucks, liquefied natural gas, etc.). Di Gregorio, R., Skjærset Nustad, S. (2017): op. cit. p. 13-14. ; Stopford, M. (2009): Maritime economics, London: Routledge.
Ship-owner - (in this context) can be a group of companies or individuals that make sure that a ship always has a cargo to move;

- $\quad$ Brokers - are intermediaries between charterers and shipowners, and

- $\quad$ Port agents - are local representatives of charterers and ship-owners that help with the logistics and communication at each port. ${ }^{24}$

It is clear that various agreements occur between all these legal entities, but as the most important contract for this paper we can single out the Charter Party which is a contract between ship-owner and charterer for the transport of commodity on the sea. ${ }^{25}$ Based on the example of the Charter party, we can show how the whole system generally works and we can point out shortcomings of the system. The whole process starts with the trader who finds a demand-supply gap through which he can profit from the margin. After finding that gap the trader makes a deal with the consignor (supplier) and the consignee (receiver), and then he gives a task to the charterer to arrange the shipping of that commodity. The charterer contacts his brokers and gives them the data on the cargo that needs to be transported. Brokers then look for an available ship that can transport that cargo. After finding a suitable ship, brokers connect those parties which then start to negotiate the terms and conditions of the carriage. If they can agree on terms and conditions of the contract, they then sign the contract, physically or via email. ${ }^{26} \mathrm{After}$ the contract is concluded, the ship transports the cargo to the agreed port and meets its obligations from the contract. If the terms and conditions of a contract have all been met by the ship-owner, the charterer makes the transfer of funds and so the contract is fulfilled from both parties. ${ }^{27}$

As we can see from the example of the tanker shipping market and Charter party, the process of moving cargo from point $A$ to point $B$ requires a lot of intermediaries, paperwork,

24. Harshvardhan (2018): op. cit. p. 9-10.

25. Harshvardhan (2018): op. cit. p. 11.

26. Directive 2000/31/EC of the European Parliament and of the Council of 8th June 2000 on certain legal aspects of information society services, in particular electronic commerce, in the Internal Market ('Directive on electronic commerce'), Official Journal L 178, 17/07/2000 P. 0001 - 0016, in Article 9, Paragraph 1, states that Member States shall ensure that their legal system allows contracts to be concluded by electronic means and that the legal requirements applicable to the contractual process neither create obstacles for the use of electronic contracts nor result in such contracts being deprived of legal effectiveness and validity on account of their having been made by electronic means. Paragraph 2 of the same Article states that Paragraph 1 shall not apply to all or certain contracts that fall into the categories that Paragraph 2 then explains. Charter Party does not fall into the categories that are explained further in Paragraph 2, and because of that there are no obstacle for Charter Party to be concluded in electronic form on the territory of the European Union.

27. For more detail about Charter Party and how it works in practice see Harshvardhan (2018): op. cit.p. 11-14. 
time and money. As the main problems we can emphasize:

- Waste of time while all these legal entities find each other;

- Exhaustive and slow negotiations about terms and conditions of the contract;

- High costs for intermediaries;

- Extensive documentation that maintains a trail between several contracting parties who communicate on multiple channels;

- Poor document management (some documents, such as the Bill of Lading, ${ }^{28}$ still need to be delivered in the original to the cargo receivers, which in the past has frequently caused delays in cases where the original of the Bill of Lading was not received on time),

- Constant need to be online in order to find clients and monitor market trends, and

- Slow international fund transfers that take several day to arrive. $^{29}$

\section{USE OF BLOCKCHAIN AND SMART CONTRACTS IN THE SHIPPING INDUSTRY}

\subsection{Aspects of the Shipping Industry Where Blockchain and Smart Contracts Could Generally Apply}

Because the above mentioned problems in the shipping industry are widespread in various segments of the industry, many stakeholders (companies, countries, ports, and government authorities) are trying to find solutions through the implementation of modern technologies. This search for a new way to tackle the numerous issues of maritime transport have accelerated since blockchain and smart contracts entered the market. Today a majority of innovative solutions and new approaches are based on these technologies.

In 2015 Israel's Wave Company started trying to implement blockchain in solving the problems of inconsistent Electronic Data Interchange and lack of trust, while in 2016 Hong Kong's Chain of Things started researching the sharing of loT (Internet of Things) ${ }^{30}$ information (through blockchain), collected with the sensors on ships and containers to relevant parties. ${ }^{31}$ However, the big breakthrough of blockchain solutions in the shipping

28. Bill of Ladding is a legal document (record of the traded goods) issued by a carrier (or their agent) to a shipper to acknowledge receipt of cargo for shipment. It contains details about the type, quantity, and destination of the cargo.

29. See Harshvardhan (2018): op. cit. p. 15-17.

30. For a more detailed description of sharing of loT information through blockchain see Si, H., Sun, C., Li, Y., Qiao, H., Shi, L. (2019): IoT information sharing security mechanism based on blockchain technology, Future Generation Computer Systems 101 p. 1028-1040., journal homepage: www.elsevier.com/locate/fgcs.

31. Shi, H., Wang, X. (2018): Research on the Development Path of Blockchain in Shipping Industry, APCIM \& ICTTE, Beijing, China, Association for Computing Machinery. ACM ISBN 978-1-4503-6604-5/18/11...\$15.00 https://doi. org/10.1145/3321619.3321671, p. 244-245. industry came in 2017, when shipping giant Maersk and his partners (IBM, Schneider Electronic, etc.) $)^{32}$ announced that they have a blockchain solution for digitizing global trade..$^{33}$ By using the earlier described advantages of blockchain, Maersk Group deem it can cut the costs of administration and processing of physical documents ${ }^{34}$, stop fraud, especially in undeveloped markets, as well as cyber-attacks. ${ }^{35}$ After Maersk Group, other important actors in the shipping industry (such as Hyundai Merchant Marine, Samsung SDM, Mitsui OSK Lines, etc.) started to look for their own blockchain solutions. As a result of such great interest there are solutions, based on blockchain and smart contracts, for:

- More efficient inter-firm information sharing system; ${ }^{36}$

- $\quad$ Simplifying paper process;

- Combating cargo fraud;

- Improving container utilization efficiency, and

- $\quad$ Saving precipitation cost of funds. ${ }^{37}$

Most of the above solutions are primarily based on blockchain, but there are also aspects of the shipping industry where smart contracts can have a very important role. For example, blockchain based smart contracts could be used to:

- $\quad$ Track the Bill of Lading and automate fund transfers ${ }^{38}$;

- $\quad$ Execute a Charter Party agreement;

- Initiate a fund transfer between a ship owner and a charterer, and

- Calculate hire and demurrages based on a pre-defined formula. ${ }^{39}$

Another interesting approach to implementation of blockchain solutions in the shipping industry is made by Hong Kong based startup 300Cubits. Most of the other companies avoid bringing cryptocurrencies into the shipping industry

32. In the Case M.8742 - IBM / MAERSK / GTD JV, European Commission has concluded that the notified operation (between Maersk, IBM and GTD JV) falls within the scope of the Merger Regulation and it declared it compatible with the internal market. Available at: https://ec.europa.eu/competition/ mergers/cases/decisions/m8742_181_3.pdf?fbclid=IwAR1Mq-o4g-wRytQ_OLEBCsfuowl9fKmviiBMhuRa66m4_Jz2OFi5pahE38, accessed: 25. September 2020.

33. They released TradeLens platform that offers "real-time access to shipping data and shipping documents, including loT and sensor data". Irannezhad, E. (2018): Is blockchain a solution for logistics and freight transportation problems? Transportation Research Procedia 00 (2018) 000-000, World Conference on Transport Research - WCTR 2019 Mumbai 26-31 May 2019, p. 3.

34. It is estimated that from overall physical transportation costs, 1/5th goes on administration and processing of physical documents.

35. Di Gregorio, R., Skjærset Nustad, S. (2017): op. cit. p. 25-26.

36. Jensen, T., Bjørn-Andersen, N. \& Vatrapu, R. (2014): Avocados crossing borders. Proceedings of the 5th ACM international conference on Collaboration across boundaries: culture, distance \& technology - CABS '14.

37. Shi, H., Wang, X. (2018): op. cit. p. 245.

38. By using smart contracts fund transfers could be automated, without intermediaries and with reduced costs. Papathanasiou A., Cole R., Murray, P. (2020): The (non-)application of blockchain technology in the Greek shipping industry, European Management Journal, doi: https:// doi.org/10.1016/j.emj.2020.04.007.

39. Harshvardhan (2018): op. cit. p. 30. 
because of the extra complications that could emerge by using unregulated virtual value, but 300 cubits is trying to launch its own cryptocurrency (based on blockchain) for the shipping industry that would be used as deposit during the booking process, whereby the shipper would lose his deposit if he should fail to show up with the cargo, and the container line would lose its deposit if it failed to load the cargo according to the agreement. $^{40}$

\subsection{Difficulties in Applying Blockchain and Smart Contracts in the Shipping Industry}

Although there are many ways of using blockchain and smart contracts in the shipping industry, the fact is that none of the mentioned solutions are widely accepted and used in the shipping industry. There are many reasons why the existing solutions are not widely accepted, but as the main factors we can emphasize the following:

- Blockchain applications are still not so easy to use and cheap enough to force changes in the existing system;

- In order to function properly, blockchain based solutions require wider usage, which in turn means that different stakeholders would need to join a broad consortiu ${ }^{41}$ and, as we have already mentioned, blockchain based solutions are still not at that level of cost-effectiveness to force the creation of such consortium;

- There are still many economic and technology promotion barriers which need to be fully resolved before the general acceptance of blockchain based solutions in the shipping industry. ${ }^{42}$

\section{THE ROLE OF THE INTERNATIONAL MARITIME ORGANIZATION (IMO)}

The International Maritime Organization (IMO) is a specialized agency of the United Nations and it is in charge of the safety, security, and environmental performance (prevention of marine and atmospheric pollution) of international shipping, which transports more than 80 per cent of global trade. ${ }^{43}$ The main purpose of IMO is to create a fair and effective regulatory framework (through conventions) for the shipping industry that can be universally adopted and implemented..$^{44}$ Conventions for

40. Di Gregorio, R., Skjærset Nustad, S. (2017): op. cit. p. 28.

41. See Harshvardhan (2018): op. cit. p. 74

42. For more details about economic and technology promotion barriers see Shi, $H$., Wang, X. (2018): op. cit. p. 246-247.

43. See http://www.imo.org/en/About/Pages/Default.aspx, accessed: 22. September 2020.

44. See http://www.imo.org/en/About/Pages/Default.aspx, accessed: 22. September 2020. which the IMO is responsible can be classified into four categories:

- maritime safety

- $\quad$ prevention of marine pollution

- liability and compensation (especially in relation to damage caused by pollution), and

- other conventions that deal with e.g.tonnage measurement, unlawful acts against shipping and salvage, etc. ${ }^{45}$

From the above we can conclude that IMO measures cover a lot of aspects of international shipping, but the process of contracting between legal entities, as well as the new technologies in the shipping industry, are largely governed by free-market practices and the conventions of the IMO do not delve significantly into that area. That is why we do not see the IMO as an institution that would take the lead in the regulation of blockchain and smart contracts. Therefore, we deem that it is necessary to look somewhere else for the solution that could help in the general application of blockchain and smart contract in the shipping industry.

\section{REGULATION OF BLOCKCHAIN AND SMART CONTRACTS IN THE EUROPEAN UNION (EU)}

Around one third of the world's merchant fleet is controlled out of Europe. Europe is thus one of the leading maritime centers of the world (it has 329 key seaports on its coastline) ${ }^{46}$ The European Union has realized the importance of maritime trade, which, amongst other things, constitutes over $75 \%$ of its external trade and about $1 / 3$ of its internal trade. ${ }^{47}$ It is therefore not surprising that the EU has put in place an extensive legislative framework for safety, environmental protection and quality shipping, which covers the entire shipping chain. An essential aspect of the modernization of shipping regulation and administration is the process of digitalization and administrative simplification - the so-called European Maritime Single Window environment ${ }^{48}$.

The European Parliament and the Council adopted Directive 2010/65/EU on reporting formalities for ships arriving in and/or departing from ports of the Member States on October 20th 2010. It created an environment that allows for the digital and centralized submission of information. The Maritime Single Window involves a rather large number of authorities, including transport, customs, border control, safety, security, health

45. See http://www.imo.org/en/About/Conventions/Pages/Home.aspx, accessed: 22 . September 2020

46. See https://ec.europa.eu/transport/modes/maritime/maritime-transport_en, accessed: 28. September 2020.

47. See https://ec.europa.eu/transport/modes/maritime/maritime-transport_en, accessed: 28. September 2020.

48. https://ec.europa.eu/transport/modes/maritime/digital-services/e-maritime_en, accessed: 28. September 2020. 
and environment ${ }^{49}$. However, it currently however does not allow for a fully harmonized application. Therefore, the Valletta Declaration was endorsed by the Council of the EU on 08 June, $2017^{50}$, highlighting the need for a fully harmonized interface and a standardized maximum data set, including the information necessary for the management of port and port terminals. All the presented measures make it clear that the European Union has put a significant focus on the modernization and digitalization of the shipping industry in general.

However, besides the general regulation of the digitalization process in the shipping industry, the European Union has also taken significant steps in the regulation of virtual currencies. Through the European directive on the prevention of money laundering and terrorist financing, the term „virtual currency“ was defined. ${ }^{51} \mathrm{~A}$ "virtual currency" is a means of exchange accepted by natural or legal persons which can be transferred, stored, and traded electronically and that is not issued or guaranteed by a central bank or a public authority. ${ }^{52}$ As such virtual currency is of relevance in the context of shipping regulation in cases where shipping contracts are structured based on block-chain or smart contract solutions that use virtual currency as a means of exchange or insurance. However, the mentioned directive does not regulate blockchain or smart contracts itself.

This is not due to the European Union not being aware of the potential of block-chain technology, but rather a consequence of the early stage and an uncertain direction this technology might take in the future. The European Commission considers blockchain to be a new technology that makes it possible for large groups of people or organizations, regardless of trust amongst them, to collectively agree on and permanently record information without the need of a third-party authority ${ }^{53}$ As such, the Commission realizes the potential value of this technology and it has approached the technological developments regarding blockchain and smart contracts through the creation of a broad EC blockchain strategy containing the creation of a

49. In detail on the national application of the Maritim Single Window see: EUROPEAN COMMISSION DIRECTORATE-GENERAL FOR MOBILITY AND TRANSPORT Directorate $D$ - Logistics, maritime \& land transport and passenger rights D.1 Maritime transport \& logistics National Single Window Guidelines, from April 17th 2015, available under https://ec.europa.eu/transport/sites/transport/files/modes/ maritime/doc/2015-06-11-nswguidelines-final.pdf.

50. Declaration of the European Ministers responsible for the Integrated Maritime Policy on Blue Growth - Valletta Declaration - 8037/17 KS/lo 1 GIP $1 B$.

51. Directive (EU) $2018 / 843$ of the European Parliament and of the Council of 30 May 2018 amending Directive (EU) 2015/849 on the prevention of the use of the financial system for the purposes of money laundering or terrorist financing, and amending Directives 2009/138/EC and 2013/36/EU (Text with EEA relevance) PE/72/2017/REV/1, OJ L 156, 19.6.2018, p. 43-74.

52. Directive (EU) 2018/843, Article 1, (2) d nr. 18 Amendments to Directive (EU) 2015/849.

53. https://ec.europa.eu/digital-single-market/en/blockchain-technologies, accessed: 28. September 2020
European blockchain partnership ${ }^{54}$, as well as the promotion of legal certainty and establishment of interoperability standards..$^{55}$ Amongst other factors, the European Commission and other European bodies have established numerous expert groups and units like the Digital Innovation and Blockchain unit that is managing the Startup Europe and Innovation Radar initiative. ${ }^{56}$ In combination with the already mentioned efforts to modernize the shipping industry and establish an EU wide framework in this field, it can be expected that the European Union will be at the forefront of the regulation and implementation of blockchain integration in the shipping sector.

\section{CONCLUSION}

Although the current attempts to implement blockchain and smart contracts in the shipping industry look promising, the analysis has shown that there are still many obstacles to overcome before blockchain and smart contracts can fully replace the existing system in the shipping industry. Many legal entities in the shipping industry are accustomed to the current system and, even though it has a lot of flaws, the complexity of shipping contractual relations makes it hard to substitute it with anything that has not previously been examined and stress tested. Therefore any new system will have to be impeccable in order to force the diverse stakeholders to join it. It is especially important to note that the previously defined stakeholders will have vastly different interest in the technology. As presented above on the example of a charter party regarding a tanker shipping operation, multiple intermediaries are involved in the entire process. It is clear that it is rather unlikely that those intermediaries have an interest in the creation of a system that would make their role obsolete or at least significantly less relevant. Therefore those subjects will either offer the most intense pushback to the technology or in time attempt to adapt their business model to the new system. Port authorities will usually be much more focused on the above mentioned public law dimension of digitalization as they work closely with numerous agencies and government organizations. Modernization for those authorities will therefore primarily be focused on the above described streamlining of procedures and the information transfer. The various other stakeholders involved in the process have, however, a strong primary interest in the civil law dimension of modernization, namely the creation of safe and effective smart contracts based on blockchain technology.

Based on this assessment the next logical question relates to the structure of a blockchain shipping contract or blockchain

54. https://ec.europa.eu/digital-single-market/en/news/european-countries-joinblockchain-partnership, accessed: 28. September 2020.

55. https://ec.europa.eu/digital-single-market/en/blockchain-technologies, accessed: 28. September 2020.

56. https://ec.europa.eu/digital-single-market/en/content/digital-innovation-andblockchain-unit-f3, accessed: 28. September 2020. 
shipping system in general. Two options come to mind, a consortium based approach and an open approach. An open approach could benefit from integration with various external stakeholders. By using datasets from public authorities that could be made available under special legal agreements and entered directly into the blockchain, the system could receive numerous external data entry points from reliable sources. This system would however require a close collaboration with multiple public authorities. Furthermore, this would raise issues relating to data protection, while the responsibility for entry errors would also have to be assigned. Due to the involved risks and challenges, it is therefore to be expected that, despite the above mentioned efforts of the EU to embrace blockchain technology, the private sector will be at the forefront of these developments.

The lack of data entry points related to generally trusted, responsible, and liquid subjects in the form of public authorities, however, will require that stakeholders in a blockchain system to have at least a basic level of trust amongst each other, in order to ensure a common interest in the general functionality of the system. This will certainly lead to the focusing on consortium based blockchain solutions. These solutions might be still related to information that is also delivered to public authorities or other bodies. However, the responsibility for data entry is most likely to be assigned to the private subjects that are issuing or controlling certain data.

Therefore, it is our opinion that the future of blockchain technology in the shipping sector will be based on a broad consortium based approach for the general use of the new system based on blockchain and smart contracts. Blockchain technology is developing quickly and it is rapidly becoming more practical, cheaper, faster, and more convenient to adopt. If we add artificial intelligence solutions, such as Natural Language Processing (NLP), into our considerations, we are certain that new consortium based blockchain systems will be ready within a reasonable timeframe to replace the current traditional systems. In this regard it is important to point out that early adaptations of such systems will certainly require complex and wide reaching traditional consortium contracts, in order to establish a basic level of trust, necessary for the system to function properly in the first place. Starting from consortium based solutions, however, it could in the future be possible that other stakeholders, especially the EU and its member states, enter this field, both through regulation, as well as through an active involvement in the systems.

From the above considerations we can conclude that at this point in time there is still no need for legal regulation of blockchain and smart contracts in the shipping industry. This is because it is currently unclear how the new system will be designed before it can fully replace the existing organization of the shipping industry. The very minimum of information for adequate regulation would be to know which entities will be involved in the system, what their rights and obligations will be, and how a verification system will be designed. While we have some indicators, showing that stakeholders will be the main driving forces behind the technologies, this is not enough to present an entire legal framework. Furthermore, the roles of all participants will strongly depend on the technical feasibility of certain solutions and the specific arrangements between the involved parties. Therefore it is still too early to identify the necessary facts to create a quality regulatory framework, whereby it is better to wait for the system to evolve, rather than to act prematurely by overregulating this field, thereby preventing its development.

\section{REFERENCES}

Acciaro, M. et al., 2018. Are the innovation processes in seaport terminal operations successful? Maritime Policy \& Management, 45(6), pp.787-802. Available at: http://dx.doi.org/10.1080/03088839.2018.1466062.

Arduino, G. et al., 2013. How to turn an innovative concept into a success? An application to seaport-related innovation. Research in Transportation Economics, 42(1), pp.97-107. Available at:

http://dx.doi.org/10.1016/j.retrec.2012.11.002.

Babich, V. \& Hilary, G., 2018. What Operations Management Researchers Should Know About Blockchain Technology. SSRN Electronic Journal. Available at: http://dx.doi.org/10.2139/ssrn.3131250.

Bavassano, G., Ferrari, C. \& Tei, A., 2020. Blockchain: How shipping industry is dealing with the ultimate technological leap. Research in Transportation Business \& Management, 34, p.100428. Available at:

http://dx.doi.org/10.1016/j.rtbm.2020.100428.

Blocher, W., 2016. The next big thing: Blockchain - Bitcoin - Smart Contracts, 71. Deutsche Juristentag - Anwaltsblatt 8-9.

Blossey, G., Eisenhardt, J. \& Hahn, G., 2019. Blockchain Technology in Supply Chain Management: An Application Perspective. Proceedings of the 52nd Hawaii International Conference on System Sciences. Available at:

http://dx.doi.org/10.24251/hicss.2019.824.

Bouidani, M.M., 2019. Design and Implementation of Blockchain Shipping Application, A Thesis Submitted in Partial Fulfilment of the Requirements for Degree of Master of Applied Science in the Department of Electrical and Computer Engineering, University of Victoria.

Buterin, V., 2015. Crypto Renaissance Salon - On Public and Private Blockchains. Available at: https://blog.ethereum.org/20l5/08/07/on-public-and-privateblockchains.

Clott, C., Hartman, B. \& Beidler, B., 2020. Sustainable blockchain technology in the maritime shipping industry. Maritime Supply Chains, pp.207-228. Available at: http://dx.doi.org/10.1016/b978-0-12-818421-9.00011-2.

Cong, L.W. \& He, Z., 2019. Blockchain Disruption and Smart Contracts. The Review of Financial Studies, 32(5), pp.1754-1797. Available at:

http://dx.doi.org/10.1093/rfs/hhz007.

Di Gregorio, R., Skjærset Nustad, S., 2017. Blockchain adoption in the shipping industry, A study of adoption likelihood and scenario-based opportunities and risks for IT service providers, Copenhagen Business School, Number of STUs: 272,322. 
European Commission - Blockchain Technologies, 2020. Available at: https:// ec.europa.eu/digital-single-market/en/blockchain-technologies.

European Commission - Digital Innovation and Blockchain (Unit F.3), 2020. Available at: https://ec.europa.eu/digital-single-market/en/content/digital-innovation-andblockchain-unit-f3.

European Commission - European Countries Join Blockchain Partnership, 2020. Available at: https://ec.europa.eu/digital-single-market/en/news/europeancountries-join-blockchain-partnership.

European Commission - Maritime Transport, 2020. Available at: https://ec.europa. eu/transport/modes/maritime/maritime-transport_en.

European Commission - Mobility and Transport, 2020. Available at: https:// ec.europa.eu/transport/modes/maritime/digital-services/e-maritime_en.

European Commission - National Single Window Guidelines, 2020. Available at: https://ec.europa.eu/transport/sites/transport/files/modes/maritime/doc/2015-0611-nswguidelines-final.pdf.

European Commission, 2018. Available at: https://ec.europa.eu/competition/ mergers/cases/decisions/m8742_181_3.pdf?fbclid=IwAR1Mq-o4g-wRytQ_OLEBCsfuowl9fKmviiBMhuRq66m4_Jz2OFi5pahE38.

Gans, J., 2019. The Fine Print in Smart Contracts. Available at: http://dx.doi.org/10.3386/w25443.

Harshvardhan, 2018. Improving shipping contracts with the use of emerging technologies, Master of Engineering in Supply Chain Management at the Massachusetts Institute of Technology.

IMO Conventions, 2020. Available at: http://www.imo.org/en/About/Conventions/ Pages/Home.aspx.

IMO, 2020. Available at: http://www.imo.org/en/About/Pages/Default.aspx.

Irannezhad, E., 2020. Is blockchain a solution for logistics and freight transportation problems? Transportation Research Procedia, 48, pp.290-306. Available at: http://dx.doi.org/10.1016/j.trpro.2020.08.023.

Jain, P., 2018. Improving the process of container shipping using blockchain, Master of Applied Science in Supply Chain Management at the Massachusetts Institute of Technology.

Jensen, T., Bjørn-Andersen, N. \& Vatrapu, R., 2014. Avocados crossing borders. Proceedings of the 5th ACM international conference on Collaboration across boundaries: culture, distance \& technology - CABS'14. Available at: http://dx.doi.org/10.1145/2631488.2631500.

Kiviat, T.I., 2015. Beyond Bitcoin: Issues In Regulating Blockchain Transactions, 65 Duke Law Journal.

Kütük-Markendorf, M.E., 2016. Rechtliche Einordnung von Internetwährungen im deutschen Rechtssystem am Beispiel von Bitcoin. Available at: http://dx.doi.org/10.3726/b10492.

Nakamoto, S., 2008. Bitcoin: A Peer-to-Peer Electronic Cash System. Available at: https://bitcoin.org/bitcoin.pdf.

Papathanasiou, A., Cole, R. \& Murray, P., 2020. The (non-)application of blockchain technology in the Greek shipping industry. European Management Journal.
Available at:

http://dx.doi.org/10.1016/j.emj.2020.04.007.

Pečarić, M., Peronja, I. \& Mostarac, M., 2020. Application of "blockchain" and "smart contract" tehnology in international payments - the case of reimbursement banks. Pomorstvo, 34(1), pp.166-177. Available at: http://dx.doi.org/10.31217/p.34.1.18.

Perkušić, M, Jozipović, Š., Mamut, J., 2020. Mogućnosti korištenja i pravnog uređenja tzv. pametnih ugovora u Republici Hrvatskoj, Hrvatsko obvezno pravo u poredbenopravnom kontekstu: Petnaest godina Zakona o obveznom odnosima, Ekonomski fakultet Sveučilišta u Zagrebu, Zagreb.

Perkušić, M., 2019. Legal Issues of Electronic Payment, Doctoral Dissertation, University of Rijeka, Faculty of Law.

Pflaum, I., Hateley, E., 2014. A bit of a problem: National and extraterritorial regulation of virtual currency in the age of financial disintermediation, Georgetown Journal of International Law, vol. 45.

Pilavci, E. E., 2019. The Regulation of Smart Contracts: Law, Governance and Practice, ISTANBUL BILGI ÜNIVERSITESI LISANSÜSTÜ PROGRAMLAR ENSTITÜSÜ BILIŞIM VE TEKNOLOJI HUKUKU YÜKSEK LISANS PROGRAMI.

Ryan, P., 2017. Smart Contract Relations in e-Commerce: Legal Implications of Exchanges Conducted on the Blockchain. Technology Innovation Management Review, 7(10), pp.14-21. Available at: http://dx.doi.org/10.22215/timreview/1110.

Seebacher, S. \& Schüritz, R., 2017. Blockchain Technology as an Enabler of Service Systems: A Structured Literature Review. Exploring Services Science, pp.12-23. Available at:

http://dx.doi.org/10.1007/978-3-319-56925-3_2.

Shi, H. \& Wang, X., 2018. Research on the Development Path of Blockchain in Shipping Industry. Proceedings of the Asia-Pacific Conference on Intelligent Medical 2018 \& International Conference on Transportation and Traffic Engineering 2018 on - APCIM \& ICTTE 2018. Available at: http://dx.doi.org/10.1145/3321619.3321671.

$\mathrm{Si}, \mathrm{H}$. et al., 2019. IoT information sharing security mechanism based on blockchain technology. Future Generation Computer Systems, 101, pp.1028-1040. Available at: http://dx.doi.org/10.1016/j.future.2019.07.036.

Stopford, M., 2009. Maritime Economics. Available at: http://dx.doi.org/10.4324/9780203891742.

Szabo, N., 1994. Smart Contracts, retrived from: http://www.fon.hum.uva.nl/rob/ Courses/InformationInSpeech/CDROM/Literature/LOTwinterschool2006/szabo. best.vwh.net/smart.contracts.html.

Tapscott, D., Tapscott, A., 2017. How blockchain will change organizations, MIT Sloan Management Review, 58(2)

Vanelslander, T., Sys, C., Carlan, V., 2016. Innovation among seaport operators: A QCA approach for determining success conditions, International Journal of Transport Economics, 43

Zheng, Z., Xie, S., Dai, H., Chen, W., Chen, X., Weng, J., Irman, M., (2019): An Overview on Smart Contracts: Challenges, Advances and Platforms, Journal Pre-proof, To appear in : Future Generation Computer Systems, PII: S0167-739X(19)31628-0. 